\title{
NAHDLATUL ULAMA DAN PERANNYA DALAM MENYEBARKAN NILAI-NILAI PENDIDIKAN ASWAJA AN-NAHDLIYAH PADA MASYARAKAT PLURAL
}

\author{
Ilma Kharismatunisa' \\ Institut Agama Islam Syarifuddin Lumajang, Indonesia \\ Email: ilmakharisma1@gmail.com \\ Mohammad Darwis \\ Institut Agama Islam Syarifuddin Lumajang, Indonesia \\ Email: mohammad.darwis70@gmail.com
}

\begin{abstract}
Abstrak: Artikel ini hendak menjelaskan tentang penanaman nilai-nilai pendidikan Aswaja untuk melihat tumbuh kembangnya kehidupan keberagamaan. Proses penanaman nilai-nilai pendidikan Islam Aswaja sejatinya tidak hanya terjadi di lingkungan pendidikan formal saja. Lebih dari itu, nilai-nilai pendididikan aswaja sudah menjadi tradisi kuat yang terus dipertahankan masyarakat Nahdlatul Ulama. Artikel ini ditulis dengan menggunakan pendekatan kualitatif dengan lokasi penelitian di Kecamatan Senduro Lumajang. Kesimpulan menunjukkan bahwa nilai-nilai pendidikan Aswaja An-nahdliyyah yang ditanamkan pada masyarakat plural di Kecamatan Senduro mencakup beberapa aspek yaitu tawasuth, tasamuh, i'tidal dan tawazun. Peran Nahdlatul Ulama dalam proses penanaman nilai-nilai tawasuth dilakukan dengan metode pemahaman dan metode pembiasaan. Sedangkan penanaman nilai-nilai tasamuh dilakukan melalui program-program kegiatan MWCNU Senduro dengan metode pemahaman. Untuk penanaman nilai-nilai i'tidal dilakukan dengan metode pemahaman dan metode pembiasaan dan nilai-nilai tawazun dikemas dengan metode pemahaman dan metode pembiasaan.
\end{abstract}

Kata Kunci: Nahdlatul Ulama, Penyebaran Nilai Aswaja An-Nahdliyah, Masyarakat Plural

\section{Pendahuluan}

Negara Indonesia merupakan negara yang berbasis plural dan multikultural.

Plural dan multikultural Indonesia tampak pada keragaman bahasa, agama, etnis, budaya, suku dan tradisi. Indonesia terdiri dari bermacam-macam ras, suku bangsa dan agama serta kaya akan bahasa. Keragaman tersebut memberikan keuntungan dan kekayaan bagi negeri, tapi disisi lain akan menjadi ancaman yang besar menimbulkan konflik sosial, politik, agama serta budaya apabila keragaman tersebut tidak kelola dengan baik. Keberagaman ini menimbulkan banyak perseteruan seperti yang di negara kita baru-baru ini. Banyak dari masyarakat kalangan-kalangan tertentu di 
Indonesia yang belum bisa menerima perbedaan, bahkan diperparah dengan masuknya aliran transnasional sebagaimana disebutkan oleh Ahmad Ihwanul Muttaqin dalam artikel jurnalnya. Menurutnya, belakangan kondisi keberagamaan masyarakat Islam (baca: Islamisme) di Indonesia mulai bergeser dengan munculnya berbagai kelompok Islam 'baru', bahkan termasuk Islam yang Radikal. Kelompok baru ini datang membawa faham ideologi keagamaan yang dinilai berbeda dengan ideologi lokal, bahkan mempunyai jaringan internasional atau transnasional. ${ }^{1}$

Masyarakat Indonesia dikenal sebagai masyarakat plural, yang memiliki beragam suku, agama dan budaya. Plurarisme di Indonesia menjadi aset yang sangat tinggi nilainya. Akan tetapi ada wacana dalam masyarakat yang menimbulkan perbedaan-perbedaan yang memunculkan potensi ke arah konflik. Seringkali kali potensi konflik ini menjadi kenyataan yang menjadi sumber-sumber perbedaan sehingga berpengaruh negatif pada perbedaan dalam menyikapi latar belakang agama. Di Indonesia banyak terjadi konflik sosial yang mengatasnamakan agama dan berakhir pada ketidaktoleransian satu sama lain. Contoh yang sederhana adalah maraknya kasus ujaran kebencian dan bahkan dibanyak kasus dibungkus dengan kedok agama.

Apabila bangsa ini ingin menjadi kuat, maka diperlukan sikap untuk saling menghargai, memahami, menghormati dan saling menerima dari tiap-tiap individu yang beragam, sehingga dapat saling membantu dan bekerja sama dalam membangun negara menjadi lebih baik. Untuk mempunyai individu-individu yang bertanggung jawab atas dirinya sendiri dan menghormati individu lainnya diperlukan adanya pemahaman, bahwa perbedaan bukan menjadi persoalan. Yang penting adalah bagaimana menjadikan perbedaan-perbedaan tersebut menjadi indah, dinamis dan membawa berkah.

Pendidikan diyakini memiliki peran yang besar dalam membentuk karakter individu-individu yang di didiknya, dan mampu menjadi “guilding light” bagi generasi muda penerus bangsa. Ahmad D Rimba menyebutkan bahwa pendidikan adalah

\footnotetext{
${ }^{1}$ Ahmad Ihwanul Muttaqin; Saiful Anwar, "Dinamika Islam Moderat: Studi atas Peran LP. Ma'arif NU Lumajang dalam Mengatasi Gerakan Radikal," Tarbiyatuna: Jurnal Pendidikan Islam, vol. 12, no. 1 (Februari, 2019), 21. DOI: https://doi.org/10.36835/tarbiyatuna.v12i1.350 
bimbingan atau pimpinan secara sadar oleh pendidik terhadap perkembangan asmani dan ruhani terdidik menuju kepribadian yang utama. ${ }^{2}$ Salah satu tujuan pendidikan nasional menurut UU tentang Sisdiknas menyebutkan bahwa untuk berkembangnya potensi peserta didik agar menjadi manusia yang beriman dan bertaqwa kepada Tuhan Yang Maha Esa. Dan untuk mewujudkan tujuan tersebut, dapat dilakukan melalui pendidikan agama Islam.

Pendidikan Islam adalah pendidikan menurut Islam atau pendidikan Islami, yakni pendidikan yang dipahami dan dikembangkan dari ajaran dan nilai-nilai fundamental dan terkandung dalam sumber dasarnya, yaitu Al-Qur'an dan asSunnah. ${ }^{3}$ Pendidikan agama Islam di Indonesia adalah pendidikan dengan mempertimbangkan tuntutan untuk menghargai agama lain dalam hubungan kerukunan antar umat beragama untuk mewujudkan persatuan Indonesia. Pendidikan Agama Islam tidak terlepas dari penanaman dan pembentukan nilai-nilai religius. Penanaman dan pembentukan nilai religius menjadi aspek penting dalam menumbuhkan karakter menjadi manusia yang beriman, bertaqwa kepada Allah SWT, kepribadian yang bertanggung jawab terhadap bangsa dan negara.

Penanaman nilai-nilai pendidikan agama Islam merupakan upaya untuk menanamkan atau memahamkan nilai-nilai pendidikan yang mencerminkan tumbuh kembangnya kehidupan dalam beragama yang terdiri dari tiga unsur pokok yaitu aqidah, akhlak dan ibadah yang menjadi pedoman berperilaku sesuai aturan dalam AlQur'an. Proses penanaman nilai-nilai pendidikan Islam tidak hanya terjadi di lingkungan pendidikan formal saja, akan tetapi juga diaplikasikan didalam masyarakat melalui organisasi kemasyarakatan yaitu Nahdlatul Ulama.

Nahdlatul Ulama adalah organisasi masyarakat terbesar yang bergerak di bidang pendidikan, sosial dan keagamaan yang ada di Indonesia yang didirikan oleh KH. Hasyim Asyari. Organisasi Nahdlatul Ulama menganut ajaran Ahlussunnah Wal Jama'ah (Aswaja). Aswaja merupakan golongan yang selalu berusaha berada pada

${ }^{2}$ H. Mahmud. "Problematika Pendidikan Islam dan Upaya-Upaya Pemecahannya", Jurnal Manajemen Pendidikan Islam, vol. 3, no.1, (14 Februari 2020), 6.

${ }^{3}$ Robiatul Adawiyah; Ahmad Ihwanul Muttaqin, "Kiai Langgar sebagai Episentrum Pendidikan Islam Masyarakat Desa Meninjo Ranuyoso Lumajang", Tarbiyatuna: Jurnal Pendidikan Islam, vol. 13, no. 1 (Februari, 2020), 3. DOI: https://doi.org/10.36835/tarbiyatuna.v13i1.606 
garis kebenaran As Sunnah Wal Jama'ah. ${ }^{4}$ Dalam bidang ilmu fiqih, NU mengikuti salah satu dari empat madzab yaitu Madzhab Hanafi, Maliki, Syafi'i dan madzhab Hambali. Nahdlatul Ulama didirikan pada tanggal 31 Januari 1926, dan sampai sekarang mampu merekrut banyak anggota yang tersebar di seluruh wilayah Indonesia. Nahdlatul Ulama memiliki pengurus disetiap tingkatan dan badan otonom yang berfungsi melakukan tugasnya masing-masing. Di tingkat nasional ada Pengurus Besar Nahdlatul Ulama (PBNU), tingkat propinsi ada Pengurus Wilayah Nahdlatul Ulama (PWNU), tingkat kabupaten ada Pengurus Cabang Nahdlatul Ulama (PCNU), tingkat kecamatan ada Majelis Wakil Cabang (MWC) dan ditingkat desa ada Ranting serta dengan badan otonom yang lain.

Nahdlatul Ulama memiliki landasan filosofis yaitu Ahlussunnah Wal Jama'ah. Aswaja adalah merekalah yang mengikuti dan berpegang teguh dengan sunnah nabi dan sunnah Khulafaur Rosyidin setelahnya. Mereka adalah kelompok yang selamat (Al firqah al-Najiyah). Pendidikan Islam yang selalu diterapkan Ahlusunnah Wal Jama'ah yang diamalkan NU, yaitu prinsip-prinsip yang selalu diajarkan oleh Rasulullah dan para Sahabatnya yakni: Tawassuth (bersikap tengah-tengah atau moderat), Tawazun (seimbang), Tasamub (toleransi), I'tidal (adil atau tegak lurus) dan Amar Ma'ruf Nahi Munkar. Allah telah menjelaskan bahwa umat Nabi Muhammad SAW adalah ummat wasath, umat pertengahan yang adil dalam Q.S Al-Baqarah: 143.

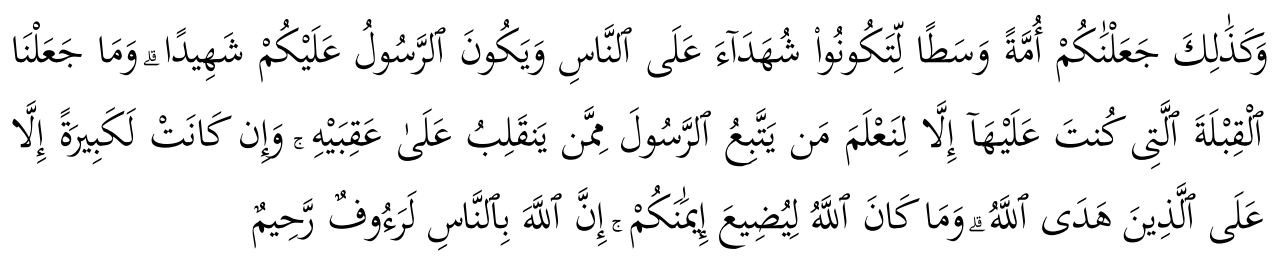

Artinya : Dan demikian (pula) Kami telah menjadikan kamu (umat Islam), umat yang adil dan pilihan agar kamu menjadi saksi atas (perbuatan) manusia dan agar Rasul (Mubammad) menjadi saksi atas (perbuatan) kamu. Dan Kami tidak menetapkan kiblat yang menjadi kiblatmu (sekarang) melainkan agar Kami mengetahui (supaya nyata) siapa yang mengikuti Rasul dan siapa yang membelot. Dan sunggub (pemindahan kiblat) itu terasa amat berat, kecuali bagi orang-orang yang telah diberi petunjuk oleh

${ }^{4}$ Ach. Masduqi, Konsep Dasar Pengertian Ablus Sunnah Wal Jama'ah (Surabaya: Pelita Dunia Surabaya, 1996), 12.

144 | Tarbiyatuna: Jurnal Pendidikan Islam; Volume 14, Nomor 2, Agustus 2021 p-ISSN: 2085-6539; e-ISSN: 2242-4579; 141-163 
Allab; dan Allah tidak akan menyia-nyiakan imanmu. Sesungguhnya Allah Maba Pengasib lagi Maha Penyayang kepada manusia. (Q.S Al-Baqarah: 143) ${ }^{5}$

Pendidikan Islam Aswaja An-Nahdliyah ditanamkan bukan hanya pada lembaga formal saja, akan tetapi juga informal melalui organisasi-organisasi masyarakat Nahdlatul Ulama. Nahdlatul Ulama tersebar luas di seluruh wilayah Indonesia yang notabene Indonesia adalah negara dengan ras, suku, bangsa serta agama yang beragam. Nahdlatul Ulama menjadi organisasi masyarakat yang besar dan diterima oleh mayoritas masyarakat Indonesia serta mampu bertahan hingga saat ini semakin banyak yang mengikuti.

Kecamatan Senduro adalah kecamatan yang terdiri dari masyarakat plural. Masyarakat yang memiliki beberapa kebudayaan dan agama yang berbeda. Di Senduro terdapat Pure Mandara Giri Agung Semeru, pure terbesar di Asia Tenggara yang menjadi tempat peribadatan umat Hindu. Begitu juga dengan umat Islam disana memiliki tempat ibadah berupa Masjid dan Musholla yang berdekatan dengan pure, sehingga kondisi ini sangat mengkhawatirkan, namun umat Islam dan Hindu di Senduro tetap hidup berdampingan antara satu dengan yang lainnya.

Komposisi masyarakat Kecamatan Senduro berdasarkan Agama sebanyak 43.123 yaitu pemeluk Agama Islam 38.357, Agama Hindu 4.667, Agama kristen 82, sedangkan Agama katolik 17 pemeluk. $^{6}$ Melihat adanya masyarakat plural di Kecamatan Senduro, Kecamatan Senduro cenderung akan terjadi konflik karena perbedaan agama tersebut. Untuk membina kerukunan antar pendatang dan masyarakat setempat, diperlukan adanya pemahaman yang sama tentang nilai-nilai tawassuth (nilai tengah-tengah), tasamub (toleransi), i'tidal (tegak lurus) dan tawazun (seimbang), agar tercipta masyarakat yang saling menghargai, menghormati, tolong menolong dan saling memahami.

Organisasi Nahdlatul Ulama tingkat kecamatan MWCNU (Majelis Wakil Cabang Nahdlatul Ulama) menjadi salah satu media pendidikan nilai-nilai Aswaja AnNahdliyah pada masyarakat kecamatan Senduro. Umat Islam dan Hindu di kecamatan Senduro hidup berdampingan dengan rukun dan harmonis, saling 
membantu dan tolong menolong. Hal tersebut terjadi karena peran Organisasi MWCNU dalam menanamkan nilai-nilai Aswaja An-Nahdliyah agar terciptanya kehidupan yang damai. Pengurus dan badan otonom Nahdlatul Ulama di Kecamatan Senduro juga aktif, terbukti dengan banyak kegiatan keagamaan yang terlaksana disana. Kegiatan-kegiatan bernuansa Islam Ahlussunnah Wal Jama'ah di kecamatan Senduro rutin dilaksanakan, baik itu kegiatan mingguan, bulanan atau tahunan. Dan di dalam salah satu kegiatan keagamaan tahunan di kecamatan Senduro yaitu peringatan hari santri, para pacalang (petugas pengaman kegiatan keagamaan hindu) ikut membantu mengamankan kegiatan tersebut. Walaupun ada beberapa BANOM (Badan Otonom) Nahdlatul Ulama yang baru berdiri dan ada yang belum aktif dikarenakan masih fokus pada pembenahan BANOM (Badan Otonom) NU yang lain. $^{7}$

Contoh kasus yang pernah terjadi di kecamatan Senduro, yaitu perusakan candi milik masyarakat beragama Hindu. Perusakan tersebut dilakukan oleh orang yang tidak bertanggung jawab dan sampai hari ini tidak diketahui siapa pelaku dari perusakan tersebut. Perusakan candi bertujuan untuk memprovokasi antara umat Hindu dengan umat Islam yang berada di kecamatan Senduro. Masalah tersebut tidak sampai meluas menjadi hal yang besar karena peran tidak ada indikasi masyarakat kecamatan Senduro yang melakukan perusakan tersebut. ${ }^{8}$

Artikel ini ditulis dengan pendekatan kualitatif fenomenologis. Sumber data diperoleh dari pimpinan dan anggota organisasi Nahdlatul Ulama tingkat Kecamatan (MWC NU) dan masyarakat di kecamatan yang sama.

\section{Peran Nahdlatul Ulama}

Peran yaitu tindakan atau perilaku yang berpengaruh atau mempengaruhi terhadap suatu masyarakat. Menurut Soerjono Soekanto peran merupakan aspek dinamis kedudukan (status), apabila seseorang melaksanakan hak dan kewajibannya sesuai dengan kedudukannya, maka ia menjalankan suatu peranan. ' Sedangkan

\footnotetext{
7 Wawancara dengan Bapak Khabir Ali, M.Pd, ketua MWCNU, 02 Februari 2020.

${ }^{8}$ Wawancara dengan Bapak Imron Jalil, wakil ketua MWCNU, 22 Januari 2020.

${ }^{9}$ Soerjono Soekanto, Teori Peranan,(Jakarta: Bumi Aksara, 2002), 243.

146 | Tarbiyatuna: Jurnal Pendidikan Islam; Volume 14, Nomor 2, Agustus 2021 p-ISSN: 2085-6539; e-ISSN: 2242-4579; 141-163
} 
peranan (role) merupakan aspek dinamis dari kedudukan (status). Apabila seorang melaksanakan hak dan kewajibannya sesuai dengan kedudukannya, maka hal itu berarti dia menjalankan suatu peran. Keduanya tidak dapat dipisahkan karena yang satu tergantung pada yang lain dansebaliknya. Setiap orang mempunyai macammacam peranan yang berasal dari pola-pola pergaulan hidupnya. Hal itu sekaligus berarti bahwa peranan menentukan apa yang diperbuatnya bagi masyarakat serta kesempatan-kesempatan apa yang diberikan masyarakat kepadanya. ${ }^{10}$ Nahdlatul Ulama adalah organisasi kemasyarakatan di Indonesia yang bergerak dibidang agama, sosial, dan politik yang berpaham Ahlussunnah Wal Jama’ah.

Peran yaitu tindakan atau perilaku yang dilakukan oleh seseorang individu dan/atau kelompok, organisasi, badan, lembaga yang memiliki status atau kedudukan yang berpengaruh atau mempengaruhi terhadap suatu masyarakat atau kelompok di lingkungan tersebut.

Nahdlatul Ulama (NU) merupakan jam'iyyah diniyyah ijtima'izyah (organisasi keagamaan dan sosial kemasyarakatan) yang didirikan oleh para ulama' pada tanggal 31 Januari 1926/26 Rajab 1344 H di Surabaya. Secara Bahasa, Nahdlatul Ulama berasal dari dua kata, yaitu nabdlah (bangkit) dan ulama (cerdik cendekia yang memahami ilmu agama). Gabungan dua kata itu, secara sederhana dapat diartikan sebagai "kebangkitan ulama" atau "kebangunan ulama". Sedangkan menurut istilah, Nahdlatul Ulama adalah organisasi sosial keagamaan (jam'iyyah diniyyah ijtima'iyyah) yang berhaluan Ahlusunnah wal jama’ah yang didirikan pada 16 Rajab $1344 \mathrm{H}$ atau bertepatan pada tanggal 31 Januari 1926 M, bertempat di rumah KH. Abdul Wahab Hasbullah di desa Kertopaten Surabaya. Turut hadir dalam pertemuan tersebut, KH Hasyim Asy'ari Jombang (1871-1947), KH Bisri Sansuri Jombang (1881-1980), KH Asnawi Kudus (1861-1959), KH Ma'sum (1870-1972), KH Nawawi (Pasuruan), KH Nahrowi (Malang), KH Alwi Abdul Aziz (Surabaya) dan lain-lain. Para Ulama sepakat mendirikan jam'iyyah dengan nama jam'iyyah Nabdlatoel Oelama (NO) yang 
dipimpin oleh KH. Hasyim Asy'ari sebagai Rais Akbar dan Haji Hasan Gipo, seorang pengusaha Surabaya sebagai ketua pelaksana (tanfidriyah). ${ }^{11}$

Sebagai organisasi perkumpulan atau jam'iyyah diniyyah Islamiyyah ijtima'iyyah (organisasi keagamaan dan sosial) untuk menciptakan kemaslahatan masyarakat, kemajuan bangsa, dan ketinggian harkat dan martabat manusia, NU bertujuan untuk melestarikan berlakunya ajaran Islam yang menganut faham Ahlusunnah wal Jama'ah untuk terwujudnya tatanan masyarakat yang berkeadilan demi kemaslahatan, kesejahteraan umat dan demi terciptanya rahmat bagi semesta. ${ }^{12}$

Nahdlatul Ulama sejak berdirinya merupakan wadah perjuangan melawan penjajahan dan merebut kemerdekaan Indonesia dari para penjajah Belanda dan Jepang, sekaligus aktif berdakwah untuk menjaga satu kesatuan Negara Kesatuan Republik Indonesia. Peran Nahdlatul Ulama dalam memperjuangkan kemerdekaan Indonesia sangat besar, mempertahankan keutuhan NKRI bisa dilihat atas latar belakang lahirnya ormas terbesar di Indonesia Nahdlatul Ulama.

Ada tiga alasan terbesar lahirnya NU pada tanggal 31 Januari 1926, yaitu yang pertama, motif agama. Motif agama, Nahdlatul Ulama lahir karena semangat menegakkan dan mempertahankan agama Islam di Nusantara, meneruskan jejak walisongo. Terlebih lagi, Belanda membawa misi 3G yaitu Gold (kekayaan), Glory (kejayaan) dan Gospel (menyebarkan agama kristen-katolik). Kedua, motif mempertahankan Ahlussunnah Wal Jama'ah karena Nahdlatul Ulama lahir untuk membentengi umat Islam khususnya di Nusantara pada ajaran Ahlussunnah Wal Jama'ah (para Pengikut Sunnah Nabi, Sahabat dan Ulama Salaf Pengikut NabiSahabat), sehingga tidak mudah menerima aliran-aliran yang tidak kenal yang bersifat radikal atau membawa ajaran bid'ah yang sesat. Yang ketiga, motif nasionalisme untuk mempertahankan keutuhan dan kemerdekaan Indonesia. ${ }^{13}$ Motif nasionalisme tumbuh karena Nahdlatul Ulama lahir dengan niatan menyatukan para ulama dan tokoh agama dengan melawan penjajahan. Semangat nasionalisme itu juga terlihat

${ }^{11}$ Muchotob Hamzah, Pengantar Studi Aswaja An-Nabdliyyah, Cet III (Wonosobo: UNSIQ PRESS, 2018), 137.

${ }^{12}$ Hamzah, Pengantar Studi Aswaja An-Nabdliyyah, vi.

${ }^{13}$ Choirul Anam, Pertumbuban dan Perkembangan NU (Surabaya: Bisma Satu Press, 1998), 36.

148 | Tarbiyatuna: Jurnal Pendidikan Islam; Volume 14, Nomor 2, Agustus 2021 p-ISSN: 2085-6539; e-ISSN: 2242-4579; 141-163 
dari nama Nahdlatul Ulama yang berarti "Kebangkitan Para Ulama". Maka tidak heran jika Nahdlatul Ulama sangat bersifat nasionalisme.

Sebagai organisasi keagamaan, NU memiliki karakteristik paham dan praktik keagamaan yang mendasari seluruh perilaku dan denyut gerakan-gerakannya. Ia mendasarkan paham keagamaannya kepada al-Qur'an, hadist, ijma' dan qiyas. Dalam memahami Islam dari sumbernya, NU mengikuti paham Ahlussunnah wal Jamaah (Sunnisme) dengan menggunakan metode pendekatan sebagai berikut: mengikuti paham Abu Hasan al-Asy'ari dan Abu Mansur al-Maturidi dalam bidang teologi; mengikuti salah satu dari empat madzab (Hanafi, Maliki, Syafi'i, atau Hambali) dalam bidang Fiqh (pemikiran hukum Islam) dan mengikuti ajaran-ajaran Junaid alBaghdadi dan Al Ghazali dalam bidang tasawuf. Keterikatan NU kepada salah satu madzab merupakan salah satu ciri khas NU sebagai salah satu organisasi Islam tradisional di Indonesia. ${ }^{14}$

Landasan filosofis NU (termasuk ranah pendidikannya) adalah Ahlu Sunnah Waljamaah (ASWAJA). Ahlussunnah Wal Jam'ah adalah kelompok ahli tafsir, ahli hadist dan ahli fiqih. Merekalah yang mengikuti dan berpegang teguh dengan sunnah nabi dan sunnah Khulafaur Rosyidin setelahnya. Mereka adalah kelompok yang selamat (Al firqah al-najizah). Mereka mengatakan bahwa kelompok tersebut sekarang ini terus terhimpun dalam madzab empat, yaitu pengikut madzab Imam Hanafi, Imam Syafi'i, Imam Maliki dan Imam Hanbali. ${ }^{15}$

\section{Nilai-Nilai Pendidikan Agama Islam Aswaja An-Nahdliyah}

Pendidikan Agama Islam Aswaja An-Nahdliyah adalah pendidikan yang falsafah dasar dan tujuan serta teori-teori yang dibangun untuk melaksanakan praktek pendidikan berdasarkan nilai-nilai dasar yang sesuai dengan ajaran Ahlussunnah Wal Jama'ah ala Nahdlatul Ulama.

Nilai-nilai pendidikan agama Islam Aswaja An-Nahdliyah dalam artikel ini adalah nilai-nilai ajaran pendidikan Islam Aswaja yang diaplikasikan dalam masyarakat oleh Nahdlatul Ulama. Pendidikan adalah kegiatan memperoleh dan menyampaikan

${ }^{14}$ Faisal Ismail, NU Moderatisme dan Plurarisme, Cet I (Yogyakarta: IRCiSod, 2020), 107.
15 Muhyiddin Abdusshomad, Hujjah NU Aqidah-Amaliah-Tradisi, Cet I (Surabaya: Khalista, 2008), 6. 
pengetahuan, sehingga memungkinkan transmisi kebudayaan kita dari generasi yang satu kepada generasi berikutnya). Pendidikan hakikatnya merupakan usaha manusia untuk dapat membantu, melatih, dan mengarahkan anak melalui transmisi pengetahuan, pengalaman, intelektual dan keberagaman orang tua (pendidik) dalam kandungan sesuai dengan fitrah manusia supaya dapat berkembang sampai pada tujuan yang dicita-citakan yaitu kehidupan yang sempurna dengan terbentuknya kepribadian yang utama.

Pendidikan Agama Islam merupakan upaya yang dilakukan secara sadar dan terencana dalam menyiapkan peserta didik untuk mengenal, memahami, menghayati, mengimani, bertakwa, berakhlak mulia, mengamalkan ajaran agama Islam dari sumber utamanya kitab suci al-Qur'an dan al-Hadits, melalui kegiatan bimbingan dan pengajaran latihan.

Menurut Chabib Thoha pendidikan Islam adalah pendidikan yang falsafah dasar dan tujuan serta teori-teori yang dibangun untuk melaksanakan praktek pendidikan berdasarkan nilai-nilai dasar Islam yang terkandung dalam al-Qur'an dan Hadist. $^{16}$

Hadratusysyaikh KH. Muhammad Hasyim Asyari (1287-1336 H/1871-1947) menjelaskan di dalam kitabnya Zidayat Ta'liqat (hal 23-24), bahwa Ahlusunnah Wal Jama'ah adalah kelompok ahli tafsir, ahli hadist dan ahli fiqih. Merekalah yang mengikuti dan berpegang teguh dengan sunnah Nabi Muhammad SAW dan sunnah Khulafaur Rasyidin setelahnya. Mereka adalah kelompok yang selamat (al-Firqah alNajiyab). Mereka mengatakan, bahwa kelompok tersebut sekarang ini terhimpun dalam madzab yang empat, yaitu pengikut Madzab Hanafi, Syafi'i, Maliki dan Hanbali. $^{17}$

Hubungan antara NU dengan Aswaja adalah jika Aswaja itu sebagai reaksi terhadap faham lain, maka dapat dipahami bahwa dalam sejarah lahirnya NU adalah

\footnotetext{
16 Thoha, Kapita Selekta, 83.

${ }^{17}$ Muhyiddin Abdusshomad, Hujjah NU Akidah-Amaliah-Tradisi, (Surabaya: Khalista Surabaya, 2015 Cet VIII), 6.

150 | Tarbiyatuna: Jurnal Pendidikan Islam; Volume 14, Nomor 2, Agustus 2021 p-ISSN: 2085-6539; e-ISSN: 2242-4579; 141-163
} 
sebagai reaksi terhadap faham lain yang dianggap radikal demi untuk menyelamatkan Aswaja di Indonesia. ${ }^{18}$

Pendidikan Islam Aswaja An-Nahdliyah adalah pendidikan Islam yang sesuai dengan empat ciri Ahlusunnah Wal Jama'ah yang diamalkan NU, yaitu empat hal yang selalu diajarkan oleh Rasulullah dan para Sahabatnya yakni:

\section{Al-Tawassuth}

Tawassuth adalah suatu langkah pengambilan jalan tengah bagi dua kutub pemikiran yang ekstrem (tatharruf), misalnya antara Qadariyyah dan Jabariyyah, antara skiptualisme ortodoks dengan rasionalisme Mu'tazilah dan antara Sufisme salafi dan Sufisme falsafi. Dalam pengambilan jalan tengah ini juga disertai dengan sikap al-Iqtishad (moderat) yang tetap memberikan ruang dialog bagi para pemikir yang berbeda-beda.

Menurut KH. Said Aqil Siradj, Tawassuth ini diaplikasikan dalam langkah pengambilan hukum antara nash dan akal. Sedangkan metode berpikir secara umum mampu menggabungkan antara wahyu dan rasio. Sikap tawassuth ini mampu meredam ekstrimis tekstual dan akal. Dengan sikap tawassuth, NU akan menjadi ummatan wasathan (kelompok moderat).

Tawassuth artinya memilih jalan tengah atau moderat. Dalam konteks kehidupan bermasyarakat, Nahdlatul Ulama selalu berusaha menempatkan diri pada posisi tengah-tengah atau moderat. Kalimat tawassuth sendiri berasal dari kalimah wasathan sesuai dengan firman Allah SWT Q.S Al Baqarah: 143

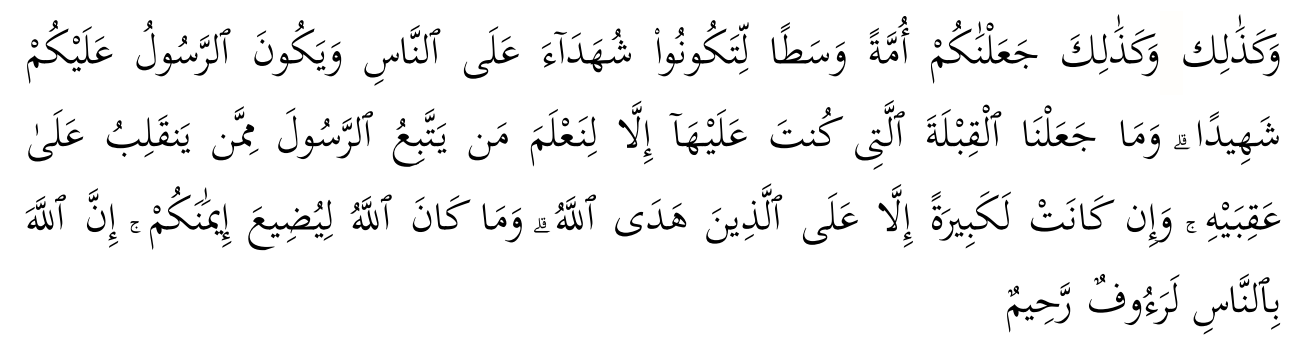

Artinya: Dan demikian (pula) Kami telah menjadikan kamu (umat Islam), umat yang adil dan piliban. Agar kamu menjadi saksi atas (perbuatan) manusia dan agar Rasul (Muhammad) menjadi saksi atas (perbuatan) kamu. Dan Kami tidak menetapkan kiblat yang menjadi kiblatmu (sekarang) melainkan agar Kami mengetahui (supaya

${ }^{18}$ KH.M. Baidlowi Muslich, Ablussunnah Wal Jama'ah, (Malang: LP3 Anwarul Huda, 2016), 46. 
nyata) siapa yang mengikuti Rasul dan siapa yang membelot. Dan sunggub (pemindahan kiblat) itu terasa amat berat, kecuali bagi orang-orang yang telah diberi petunjuk oleh Allab; dan Allab tidak akan menyia-nyiakan imanmu. Sesunggubnya Allah Maha Pengasib lagi Maha Penyayang kepada manusia. (Q.S Al Baqarah : 143) ${ }^{19}$

Dengan sikap tawassuth, NU akan menjadi ummatan wasathan (kelompok moderat). Dalam kehidupan sosial kemasyarakatan, Nahdlatul Ulama menyikapi fenomena-fenomena sosial berusaha untuk memandang suatu masalah dari banyak sisi dan mempertimbangkan banyak hal sebelum menyatakan sikap. Hal ini penting untuk menghindari fanatisme buta yang kemudian melahirkan ekstrimisme. ${ }^{20}$

2. Tasamub

Tasamub yaitu menghargai perbedaan serta menghormati orang yang memiliki prinsip hidup yang tidak sama. Namun, bukan berarti mengakui atau membenarkan keyakinan yang berbeda tersebut dalam peneguhan apa yang diyakini. Tasamuh adalah sikap toleransi, menghargai, tepa selira, tenggang rasa dan saling menghargai. Sikap yang menjadi karakteristik Nahdlatul Ulama ini sangat mempengaruhi cara pandang terhadap suatu masalah. Dengan sikap tasamuh warga Nahdlatul Ulama menempatkan keberagaman sebagai suatu keniscayaan untuk dihargai. Meski bersikap tasamub bukan berarti NU membenarkan setiap pendapat, ajaran dan paham. Tasamuh tumbuh dibawah jiwa yang fanatik terhadap ajaran-ajaran Aswaja, sehingga meskipun menghargai perbedaan-perbedaan, NU tetap teguh pada pendiriannya. ${ }^{21}$

Pendapat dari KH. Said Aqil Siradj, menyatakan bahwa nilai tasamuh ini diaplikasikan di kehidupan dalam bermasyarakat. Kehidupan yang rukun, harmonis dan damai merupakan tujuan agama Islam menjadi agama yang rahmatan lil alamin. Setiap umat Islam memiliki kewajiban untuk menciptakan lingkungan aman dan damai. Bukan hanya mampu berdamai tetapi juga mampu

\footnotetext{
${ }^{19} \mathrm{Al}-\mathrm{Qur}$ 'an, 2:143

${ }^{20}$ Hamzah, Pengantar Studi Aswaja An-Nabdliyyah, 158.

${ }^{21}$ Hamzah, Pengantar Studi Aswaja An-Nabdliyyah, 160.

152 | Tarbiyatuna: Jurnal Pendidikan Islam; Volume 14, Nomor 2, Agustus 2021 p-ISSN: 2085-6539; e-ISSN: 2242-4579; 141-163
} 
mendamaikan. Semua umat Islam adalah muslim yang senantiasa menciptakan kehidupan yang rukun, damai, harmonis dan toleran. ${ }^{22}$

\section{I'tidal}

I'tidal yaitu tegak lurus. Tidak condong kekanan maupun ke kiri atau berlaku adil dan tidak berpihak kecuali pada yang benar. Sikap i'tidal berkaitan erat dengan sikap tawassuth. Pendapat dari KH. Aqil Siradj, menyatakan bahwa i’tidal (tegak lurus atasu berlaku adil) ini diaplikasikan dalam sikap kemasyarakatan yang selalu berlaku adil antara kelompok kaya dan kelompok miskin, antara kelompok minoritas maupun mayoritas. Puncaknya adalah terbentuknya sikap gotong royong dalam menegakkan keadilan.

Pada aplikasinya, sikap I'tidal menjadi pegangan dalam mengaplikasikan sikap tawassuth. KH. Dr. As'ad Said Ali dalam pidatonya di Istanbul, menyampaikan bahwa dalam menjalankan tawassuth dan i'tidal, NU menggunakan tiga pendekatan. Pertama, fiqh al-abkam, yaitu pendekatan syari'ah untuk masyarakat yang telah siap melaksanakan hukum positif Islam (ummat ijabah). Kedua, figh al-da'wah, yakni pengembangan agama di kalangan masyarakat melalui pembinaan. Ketiga, fiqh al-siyasah, yang merupakan upaya NU dalam mewarnai politik kebangsaan dan kenegaraan. ${ }^{23}$

4. Al-Tawazun

Tawazun adalah sikap seimbang dalam berkhidmah. Menyerasikan Khidmah kepada Allah SWT, Khidmah kepada sesama manusia serta khidmah kepada lingkungan hidupnya. Menyelaraskan kepentingan kepentingan masa lalu, masa kini dan masa mendatang. Dalam mengambil keputusan, Nahdlatul Ulama selalu mendasarkan pada syura (musyawarah). Konsep ini mempertimbangkan aspekaspek keseimbangan dan kemaslahatan bersama (al-maslahih al-ammah). Ketika ada perselisihan pendapat, yang harus dikedepankan adalah al-mujadalah billati biya absan (perdebatan rasional yang di orientasikan untuk kebaikan).

Jadi nilai-nilai pendidikan Islam Aswaja An-Nahdliyah adalah sifat-sifat yang melekat pada pendidikan agama Islam yang digunakan sebagai dasar

22 Misrawi, Hadratusysyaikh Hasyim Asya'ari: Moderasi, Keumatan dan Kebangsaan, 142.

${ }^{23}$ Hamzah, Pengantar Studi Aswaja An-Nabdliyyah, 159. 
manusia untuk mencapai tujuan hidup manusia yaitu mengabdi pada Allah SWT berdasarkan ajaran Ahlussunnah Wal Jama'ah An-Nahdliyah.

\section{Masyarakat Plural}

Pluralisme adalah suatu kerangka interaksi yang mana setiap kelompok menampilkan rasa hormat dan toleran satu sama lain, berinteraksi tanpa konflik atau asimilasi (pembauran). ${ }^{24}$ Kata "plural" berasal dari bahasa Inggris yang artinya "jamak". Istilah plural atau majemuk sebenarnya berbeda dengan pengertian heterogen. Plural merupakan lawan kata dari tunggal atau singular, masyarakat plural itu bukan masyarakat yang tunggal.

Masyarakat tunggal merupakan masyarakat yang mendukung satu sistem kebudayaan yang sama, sedangkan pada masyarakat plural, di dalamnya terdapat lebih dari satu kelompok baik etnik maupun sosial yang menganut sistem kebudayaan (subkultur) berbeda satu dengan yang lain. Masyarakat kota, mungkin lebih tepat disebut sebagai masyarakat heterogen, meskipun mereka berasal dari latar belakang SARA (sukubangsa, agama, rasa atau pun aliran/golongan-golongan) yang berbeda, tetqpi mereka tidak mengelompokkan berdasarkan SARA tersebut.

Pada zaman Nabi Muhammad SAW, komunitas di Madinah lahir dari masyarakat yang plural. Tanpa masyarakat yang plural ini, tidak akan lahir Piagam Madinah yang menjadi konstitusi masyarakat Madinah pada waktu itu. Pada saat Piagam Madinah dirumuskan dan disetujui, komunitas Islam pada saat itu merupakan minoritas. Komunitas terbesar adalah Yahudi, ditambah dengan komunitas Kristen dan penganut kepercayaan Pagan. Justru dalam masyarakat yang plural itu, Nabi menjadi sebagai sosok pemersatu, tanpa melebur diri ke dalam suatu masyarakat tunggal. Dalam kesepakatan plural itu, diproklamasikan terbentuknya "masyarakat satu" (ummatan- wabidah). Namun dalam konstitusi yang merupakan kontrak sosial itu, identitas kelompok tetap diakui, namun mereka bersepakat untuk membentuk

24 Ali Maksum, Pluralisme dan Multikultural Paradigma Baru Pendidikan Agama Islam di Indonesia (Malang: Aditya Media Publishing, 2011), 79. 
solidaritas, itulah hakekat pluralisme yang merupakan reaktualisasi pluralitas di zaman klasik Islam. ${ }^{25}$

Masyarakat plural tersusun dari keanekaragaman budaya, masyarakat dan struktur sosial. Keanekaragaman adalah fakta yang tidak bisa dielakkan dalam kehidupan kolektif dan tidak bisa diharapkan eksistensinya atau tidak dapat ditekan tanpa tingkat kekerasan yang bisa diterima. Terlebih lagi sejak manusia terikat dan dibentuk oleh kebudayaan, penghormatan diri mereka secara erat terikat dengan penghormatan pada kebudayaannya. Penghormatan pada kebudayaan ini menumbuhkan rasa kesetiaan, memberi rasa percaya diri dan keberanian untuk berinteraksi dengan kebudayaan lain. ${ }^{26}$

Masyarakat plural tersusun dari keanekaragaman budaya, masyarakat dan struktur sosial. Keanekaragaman adalah fakta yang tidak bisa dielakkan dalam kehidupan kolektif dan tidak bisa diharapkan eksistensinya atau tidak dapat ditekan tanpa tingkat kekerasan yang bisa diterima. Terlebih lagi sejak manusia terikat dan dibentuk oleh kebudayaan, penghormatan diri mereka secara erat terikat dengan penghormatan pada kebudayaannya. Penghormatan pada kebudayaan ini menumbuhkan rasa kesetiaan, memberi rasa percaya diri dan keberanian untuk berinteraksi dengan kebudayaan lain.

Jadi, masyarakat plural adalah masyarakat yang di dalamnya terdapat dua atau lebih kelompok yang berbeda yang saling berinteraksi dengan toleransi dan menghormati satu sama lain tanpa adanya asimilasi.

\section{Penanaman Nilai Aswaja An-Nahdliyyah Pada Masyarakat Plural Senduro}

Kecamatan Senduro ini memiliki latar belakang kemajemukan budaya dan agama yang berbeda-beda. ${ }^{27}$ Dari aspek agama, pemeluk agama Islam berjumlah 38.357 jiwa, pemeluk agama Hindu berjumlah 4.667 jiwa, pemeluk agama Kristen berjumlah 82 jiwa dan pemeluk agama Katolik berjumlah 17 jiwa. $^{28}$ Dalam

${ }^{25}$ Budhy Munawar, Rachman, Argumen Islam untuk Pluralisme (Jakarta: PT Grasindo, 2010), XLIX.

${ }^{26}$ Casram, "Membangun Sikap Toleransi Beragama dalam Masyarakat Plural", Wawasan: Jurnal Ilmiah Agama dan Sosial Budaya, vol. 1, no. 2 (31 Mei 2020), 189.

${ }^{27}$ Khabir Aly, Wawancara, Lumajang, 05 Juni 2020, 14.00 WIB.

${ }^{28}$ Dokumentasi Kemenag Lumajang. 
masyarakat yang multiagama tersebut, diperlukan nilai-nilai Ahlussunnah Wal Jama'ah An-Nahdliyyah dalam menciptakan masyarakat yang rukun, harmonis dan saling menghargai.

MWCNU Kecamatan Senduro merupakan organisasi kepengurusan NU tingkat kecamatan yang terletak di Kecamatan Senduro. MWCNU di seluruh Indonesia memiliki tujuan, visi dan misi yang sama. Akan tetapi, nilai juang dan program-program kegiatan MWCNU di setiap daerah berbeda karena disesuaikan dengan kondisi dan kebutuhan masyarakat di lingkungan tersebut. MWCNU Kecamatan Senduro menghadapi masyarakat yang majemuk atau masyarakat plural, hal tersebut yang membuat nilai juang MWCNU Kecamatan Senduro terasa berbeda daripada MWCNU di lain daerah.

MWCNU dan masyarakat Kecamatan Senduro, dalam mengimplementasikan nilai-nilai Pendidikan Aswaja An-Nahdliyah yang ditanamkan pada masyarakat plural adalah nilai-nilai tawassuth (moderat atau sikap tengah-tengah), tasamub (toleransi), I'tidal (tegak lurus atau adil) dan tawazun (seimbang). Untuk menjaga kerukunan dan keharmonisan sikap-sikap kemasyarakatan tersebut sangat penting untuk ditanamkan mengingat Kecamatan Senduro terdiri dari masyarakat multi agama dan multi budaya. Penanaman amaliyah-amaliyah Nahdlatul Ulama juga rutin dilaksanakan oleh masyarakat di Kecamatan Senduro.

Menurut Hamzah, dalam bukunya "Pengantar Aswaja An-Nahdliyah" Dalam menjalankan paham Ahlussunnah wal Jama'ah, NU pada dasarnya menganut prinsipprinsip utama yaitu, At-tawazun (keseimbangan), at-tawassuth (moderat), at-ta'adul (patuh pada hukum) dan amr ma'ruf nahi munkar. Aswaja sebagai metode berifikir (manhaj al-fikr) keagamaan yang mencakup semua aspek kehidupan yang berdasarkan atas dasar modernisasi, menjaga keseimbangan dan toleransi. Karenanya Aswaja dapat didefinisikan sebagai "Ablu Minhaj al-fiker ad-dini al-musytamil 'ala syu'un al-hayati wa muqtadhayatiha al-qa'imi 'ala asas at-tawassuth wa at-tawazun wa at-ta'adul wa attasamuh," atau "orang-orang yang memiliki metode berfikir keagamaan yang 
mencakup semua aspek kehidupan yang berlandaskan atas dasar-dasar moderasi, menjaga keseimbangan dan toleransi." ${ }^{29}$

Hal ini yang menjadi landasan berpikir, bahwa Islam adalah agama yang rabmatan lil alamin dan Indonesia merupakan rumah bagi siapapun. Oleh karena itu, dalam penerapannya MWCNU Kecamatan Senduro selalu menanamkan Pendidikan Aswaja An-Nahdliyah kepada masyarakat plural untuk menjaga keharmonisan dan kerukunan dalam bermasyarakat yaitu penanaman sikap tawassuth, tasamuh, I'tidal dan tawazun.

\section{Penanaman Nilai-Nilai Tawassuth pada Masyarakat Plural di Senduro}

Al-Tawassuth yaitu sikap tengah-tengah, sedang-sedang, tidak ekstrim kiri ataupun ekstrim kanan. Tawassuth adalah suatu langkah pengambilan jalan tengah bagi dua kutub pemikiran yang ekstrem (tatharruf), misalnya antara Qadariyyah dan Jabariyyah, antara skiptualisme ortodokos dengan rasionalisme Mu'tazilah dan antara Sufisme salafi dan Sufisme falsafi. Dalam pengambilan jalan tengah ini juga disertai dengan sikap al-iqtishad (moderat) yang tetap memberikan ruang dialog bagi para pemikir yang berbeda-beda. ${ }^{30}$ Dengan sikap tawassuth, NU akan menjadi ummatan wasathan (kelompok moderat) serta menghindari segala bentuk pendekatan yang bersifat tatharruf (ekstrem).

MWCNU Kecamatan Senduro bersama masyarakat warga Nahdliyin bersinergi untuk membentuk insan kamil yang berpaham ablussunnah wal jama'ah yang menjunjung tingi kebersamaan dan cinta tanah air. MWCNU Kecamatan Senduro menanamkan dan mengaplikasikan nilai-nilai tawassuth dalam setiap program-program kegiatan MWCNU Senduro dan kehidupan sehari-hari. Tawassuth sejatinya sudah mengakar dalam jiwa masyarakat Nahdlatul Ulama, dan itu yang membuat masyarakat non-Islam merasa dihargai dan saling menghargai.

Peran Nahdlatul Ulama yang dilakukan oleh MWCNU Kecamatan Senduro dalam menanamkan nilai-nilai tawassuth dapat dijabarkan sebagai berikut:

1. Metode pemahaman

${ }^{29}$ Hamzah, Pengantar Studi Aswaja An-Nabdliyyah, 157.

${ }^{30}$ Achmad MuhibbinZuhri, Pemikiran KH. M. HasyimAsy'ari Tentang Abl Al-Sunnah Wa Al-Jama'ah (Surabaya: Khalista \& LTNPBNU, 2010), 61. 
Dalam menanamkan tawassuth di Kecamatan Senduro yaitu dengan memberikan pemahaman kepada masyarakat melalui kegiatan kegamaan maupun kegiatan sosial. Kegiatan keagamaan berupa kegiatan istighosah, pengajianpengajian dan lain-lain. MWCNU berusaha memberikan pemahaman atau ceramah tentang bersikap tawassuth moderat dalam bermasyarakat.

2. Metode Pembiasaan

Pembiasaan-pembiasaan yang dilakukan oleh MWCNU Kecamatan Senduro pada masyarakat dalam menanamkan nilai-nilai tawassuth, sebagai berikut:

a. Saling menghormati antar sesama manusia dalam bermasyarakat dengan berlandaskan tri ukhuwah Islam.

b. Tidak diskriminasi terhadap salah satu kelompok masyarakat, saling menghargai dan menghormati masyarakat.

c. Takziah ketika ada salah satu tetangga meninggal dunia, walaupun berbeda agama.

d. Saling menghormati ketika terjadi perbedaan faham.

e. Menerima agama mino ritas yang ada di Kecamatan Senduro.

Pendapat dari KH. Said Aqil Siradj, menyatakan bahwa Tawassuth ini diaplikasikan dalam langkah pengambilan hukum antara nash dan akal. Sedangkan metode berpikir secara umum mampu menggabungkan antara wahyu dan rasio. Sikap tawassuth ini mampu meredam ekstrimis tekstual dan akal. ${ }^{31}$ Teori tersebut sejalan dengan peran Nahdlatul Ulama dalam penanaman nilai-nilai tawassuth pada masyarakat plural di Kecamatan Senduro.

\section{Penanaman Nilai-Nilai Tasamuh pada Masyarakat Plural di Senduro}

Tasamuh merupakan sikap toleransi, menghargai, tepa selira, tenggang rasa dan saling menghargai. Sikap yang menjadi karakteristik Nahdlatul Ulama ini sangat mempengaruhi cara pandang terhadap suatu masalah. Tasamub merupakan sikap yang

\footnotetext{
${ }^{31}$ Misrawi, Hadratussyaikh Hasyim Asya'ari: Moderasi, Keumatan dan Kebangsaan, 140. 
dikembangkan dalam nilai-nilai Aswaja An-Nahdliyah untuk menunjukkan sikap saling menghargai dan menghormati prinsip hidup orang lain.

MWCNU Kecamatan Senduro menanamkan nilai-nilai tasamub kepada masyarakat plural dalam bermasyakat melalui program-program kegiatan MWCNU Kecamatan Senduro dan pembiasaan-pembiasaan yang dilakukan di dalam masyarakat, penjabarannya sebagai berikut:

1. Program-Program Kegiatan MWCNU Kecamatan Senduro

a. Peringatan HUT RI ke 73

MWCNU Kecamatan Senduro mengadakan kegiatan Peringatan HUT RI yang ke-73 pada tanggal 17 Agustus 2018 dilaksanakan di Situs Selogending Kandangan yang mengusung tema Kebhinekaan, dengan mengundang para tokoh agama Islam dan Hindu, pengurus MWCNU, Ketua PCNU, perangkat desa, lembaga Ma'arif NU, aparat keamanan, masyarakat umat Islam dan Umat Hindu setempat. Dalam upacara tersebut, selain memperingati HUT RI ke 73 juga untuk menjaga keberagaman dan toleransi beragama yang selama ini masih terjaga dengan baik.

b. Kegiatan Hari Santri Nasional Tahun 2018

MWCNU Kecamatan Senduro pada saat Hari Santri Nasional mengadakan Upacara dan pembentangan Bendera Merah Putih dan pengibaran 2200 Bendera NU. Tidak hanya melibatkan santri dan warga Nahdliyin, tetapi juga melibatkan para Pecalang (polisi adat) umat Hindu ikut dilibatkan dalam mensukseskan acara tersebut.

c. Kegiatan Pengamanan Perayaan Hari Raya Nyepi

Dalam menjaga kedamaian dan ketertiban masyarakat Kecamatan Senduro, MWCNU Kecamatan Senduro mengerahkan Banser untuk ikut membantu pengamanan karena umat Hindu dari luar daerah datang dan membutuhkan bantuan pengaturan lalu lintas.

2. Metode pembiasaan

Tidak membeda-bedakan masyarakat yang beragama lain, saling menerima dan menghargai terhadap sesama, bersatu saling mendukung satu sama lain., 
saling tolong menolong antar sesama masyarakat, dan menghormati agama yang dianut oleh masyarakat yang berbeda agama.

Pendapat dari KH Said Aqil Siradj, menyatakan bahwa nilai tasamub ini diaplikasikan dalam kehidupan dalam bermasyarakat. Kehidupan yang damai dan rukun merupakan cerminan dari tujuan agama Islam menjadi agama yang rabmatan lil alamin. Maka dalam hal ini, semua muslim memiliki tanggung jawab untuk menciptakan lingkungan yang aman dan damai. Bukan hanya mampu berdamai tetapi juga mendamaikan semua muslim, hal ini adalah muslim yang senantiasa menciptakan kehidupan yang damai dan toleran. ${ }^{32}$ Teori tersebut sejalan dengan peran Nahdlatul Ulama dalam penanaman nilai-nilai tasamuh pada masyarakat plural di Kecamatan Senduro.

\section{Penanaman Nilai-Nilai I'tidal pada Masyarakat Plural di Senduro}

I'tidal bisa diartikan tegak lurus, atau bisa pula diartikan adil. ${ }^{33}$ Pembahasan dalam temuan ini dapat disesuaikan dengan pendapat Hamzah tersebut, MWCNU Kecamatan Senduro menanamkan nilai-nilai I'tidal pada masyarakat plural di Kecamatan Senduro melalui pemahaman yang ditanamkan pada masyarakat plural dan pembiasaan-pembiasaan yang diterapkan kepada masyarakat di Kecamatan Senduro.

1. Metode pemahaman

Dalam menanamkan I'tidal di Kecamatan Senduro yaitu dengan memberikan pemahaman kepada masyarakat melalui kegiatan kegamaan maupun kegiatan sosial. Kegiatan keagamaan berupa kegiatan istighosah, pengajianpengajian dan lain-lain. MWCNU berusaha memberikan pemahaman atau ceramah tentang bersikap I'tidal dalam bermasyarakat.

2. Metode Pembiasaan

Pembiasaan-pembiasaan yang dilakukan oleh MWCNU Kecamatan Senduro pada masyarakat dalam menanamkan nilai-nilai I'tidal, sebagai berikut:

\footnotetext{
32 Misrawi, Hadratussyaikh Hasyim Aya'ari: Moderasi, 141.

${ }^{33}$ Hamzah, Pengantar Studi Aswaja An-Nabdliyyah, 158.

160 | Tarbiyatuna: Jurnal Pendidikan Islam; Volume 14, Nomor 2, Agustus 2021 p-ISSN: 2085-6539; e-ISSN: 2242-4579; 141-163
} 
a. Membantu pemerintah menyalurkan bantuan bagi masyarakat yang berhak baik yang beragam Islam maupun non-Islam.

b. Berpegang teguh pada ajaran Aswaja An-Nahdliyah

c. Mengamalkan ajaran-ajaran Nahdlatul Ulama

d. Tidak membeda-bedakan masyarakat yang berbeda budaya dan agama, memperlakukan sesuai hak dan kewajiban sesama warga Indonesia.

Pendapat dari KH. Aqil Siradj, menyatakan bahwa I'tidal (berlaku adil) ini diaplikasikan dalam sikap kemasyarakatan yang selalu berlaku adil dan terbentuknya sikap gotong royong dalam menegakkan keadilan. ${ }^{34}$ Teori tersebut sejalan dengan peran Nahdlatul Ulama dalam penanaman nilai-nilai I'tidal pada masyarakat plural di Kecamatan Senduro.

\section{Penanaman Nilai-Nilai Tawazun pada Masyarakat Plural di Senduro}

Tawazun merupakan sikap kemasyarakatan Nahdlatul Ulama yang tercantum dalam khittah NU tahun 1926. Tawazun dimaksudkan selalu menjaga keseimbangan dalam segala hal, termasuk dalam penggunaan dalil naqli (dalil yang bersumber dari al-Qur'an dan Hadist) dan dalil naqli (dalil yang bersumber dari akal rasional), seimbang antara dunia dan akhiratnya. ${ }^{35}$

MWCNU Kecamatan Senduro menanamkan nilai-nilai tawazun pada masyarakat plural di Kecamatan Senduro melalui pemahaman yang ditanamkan pada masyarakat plural dan pembiasaan-pembiasaan yang diterapkan kepada masyarakat di Kecamatan Senduro.

1. Metode pemahaman

Dalam menanamkan tawazun di Kecamatan Senduro yaitu dengan memberikan pemahaman kepada masyarakat melalui kegiatan kegamaan maupun kegiatan sosial. Kegiatan keagamaan berupa kegiatan istighosah, pengajianpengajian dan lain-lain. MWCNU berusaha memberikan pemahaman atau ceramah tentang bersikap tawazun dalam bermasyarakat.

2. Metode Pembiasaan

\footnotetext{
34 Misrawi, Hadratussyaike Hasyim Aya'ari: Moderasi, 140.
}

${ }^{35}$ Hamzah, Pengantar Studi Aswaja An-Nabdliyyah, 162. 
Pembiasaan-pembiasaan yang dilakukan oleh MWCNU Kecamatan Senduro pada masyarakat dalam menanamkan nilai-nilai tawazun, sebagai berikut:

a. Tidak terlalu berlebihan dalam berhubungan baik dengan Organisasi agama lain, pemerintah, ataupun Organisasi lainya di Senduro;

b. Berpegang teguh pada ajaran Aswaja An-Nahdliyah;

c. Mengamalkan ajaran-ajaran Nahdlatul Ulama.

Pendapat dari KH. Said Aqil Siradj, menyatakan bahwa nilai tawazun ini diaplikasikan dalam sikap politik, yaitu sikap tidak membenarkan berbagai tindakan yang ekstrim yang sering menggunakan kekerasan dalam tindakannya dan mengembangkan kontrol terhadap kekuasaan yang lazim. Keseimbangan ini mengacu pada upaya untuk mewujudkan ketentraman dan kesejahteraan bagi segenap masyarakat. ${ }^{36}$ Teori tersebut sejalan dengan peran Nahdlatul Ulama dalam penanaman nilai-nilai Tawazun pada masyarakat plural di Kecamatan Senduro.

\section{Kesimpulan}

Dari penjelasan di atas dapat disimpulkan bahwa nilai-nilai pendidikan aswaja an-nahdliyyah yang ditanamkan pada masyarakat plural di Kecamatan Senduro adalah 4 sikap kemasyarakatan yaitu tawassuth (tengah-tengah), tasamub (toleransi), i'tidal (tegak lurus) dan tawazun (seimbang) dan dilakukan dengan cara sebagai berikut:

1. Penanaman nilai-nilai tawassuth dilakukan dengan metode pemahaman. Yakni MWCNU memberi ceramah tentang nilai-nilai tawassuth dalam kegiatan sosial dan kegamaan. Selain itu juga digunakan metode pembiasaan, MWCNU membiasakan untuk bersikap tidak mendiskriminasi agama lain.

2. Penanaman nilai-nilai i'tidal pada masyarakat plural di Kecamatan Senduro melalui beberapa metode yaitu, metode pemahaman, MWCNU memberi ceramah tentang nilai-nilai i'tidal dalam kegiatan sosial kegamaan dan metode pembiasaan, MWCNU membiasakan untuk berpegang teguh pada ajaran Aswaja

${ }^{36}$ Misrawi, Hadratussyaikh Hasyim Aya'ari: Moderasi, 141. 
An-Nahdliyah dan membantu pemerintah baik kepada muslim maupun Non Islam.

3. Penanaman nilai-nilai tawazun pada masyarakat plural di Kecamatan Senduro melalui beberapa metode yaitu, metode pemahaman MWCNU memberi ceramah tentang nilai-nilai tawazun dalam kegiatan sosial keagamaan dan metode pembiasaan, MWCNU membiasakan untuk bersikap tidak berlebihan.

\section{Referensi}

Abdusshomad, Muhyiddin. 2008. Hujjah NU Aqidab-Amaliah-Tradisi. Surabaya: Khalista.

Adawiyah, Robiatul; Muttaqin, Ahmad Ihwanul, "Kiai Langgar sebagai Episentrum Pendidikan Islam Masyarakat Desa Meninjo Ranuyoso Lumajang", Tarbiyatuna: Jurnal pendidikan Islam, vol. 13, no. 1 (Februari, 2020), 1-21. DOI: https://doi.org/10.36835/tarbiyatuna.v13i1.606

Mahmud, "Problematika Pendidikan Islam dan Upaya-Upaya Pemecahannya", Jurnal Manajemen Pendidikan Islam, vol. 3, no. 1 (2020).

Maksum, Ali. 2011. Pluralisme dan Multikultural Paradigma Baru Pendidikan Agama Islamdi Indonesia. Malang: Aditya Media Publishing.

Martahan Sitompul, Einar. 2010. NU \& Pancasila. Yogyakarta: LkiS Yogyakarta.

Masduqi, Ach. 1996. Konsep Dasar Pengertian Ablus Sunnah Wal Jama'ah. Surabaya: Pelita Dunia Surabaya.

Misrawi, Zuhairi. 2010. Hadratusy Syaikh Hasyim Asya'ari: Moderasi, Keumatan dan Kebangsaan. Jakarta: Kompas.

Munawar, Budhy dan Rachman. 2010. Argumen Islam untuk Pluralisme. Jakarta: PT Grasindo.

Muslich, Baidlowi. 2016. Ahlussunnah Wal Jama’ah. Malang. LP3 Anwarul Huda.

Mustofa, Bisri. 2016. Nilai-Nilai Pendidikan Agama Islam Dalam Al-Qur'an Surat AlIsra' Ayat 23-24. Skripsi, Program Studi Pendidikan Agama Islam, Universitas Islam Negeri Maulana Malik Ibrabim. Malang.

Muttaqin, Ahmad Ihwanul; Anwar, Saiful, "Dinamika Islam Moderat, Studi atas Peran LP. Ma'arif NU Lumajang dalam Mengatasi Gerakan Radikal," Tarbiyatuna: Jurnal Pendidikan Islam, vol. 12, no. 1 (Februari, 2019), 20-38. DOI: https://doi.org/10.36835/tarbiyatuna.v12i1.350

Poerdanminto, W. J. S. 1994. Kamus Besar Bahasa Indonesia. Jakarta: Balai Pustaka.

Soekanto, Soerjono. 2002. Teori Peranan. Jakarta: Bumi Aksara.

Yaqin, Ainul. 2005. Pendidikan Multikultural; Cross-cultural Understanding untuke Demokrasi dan Keadilan. Yogyakarta. Pilar Media. 